\title{
Regional price dynamics in Argentina (2016-2019)
}

\author{
Fernando Antonio Ignacio \\ González \\ Instituto de Investigaciones \\ Económicas y Sociales del Sur, \\ UNS/CONICET, \\ Argentina \\ E-mail: \\ Fernando_gonzalez01@hotmail.com \\ This work investigates compliance with the \\ Law of One Price (LOP) across regions of \\ Argentina. A convergence and cointegration \\ analysis of the 2016-2019 period is \\ conducted using the series of the Total Basic \\ Basket (TBB) and the Consumer Price Index \\ (CPI) published by the National Institute of \\ Statistics and Census (INDEC in Spanish) on \\ a monthly basis for six regions in Argentina. \\ The results suggest the existence of \\ convergence in prices and cointegration \\ across regions, which is consistent with \\ compliance with the LOP. This is especially \\ relevant for its potential impact on regional \\ poverty disparity. Indeed, if poorer regions \\ Keywords: with lower prices tend to have a greater \\ Law of One Price, increase in price levels - and therefore \\ convergence, convergence is observed - this may imply an \\ regional disparities increase in regional disparities.
}

\section{Introduction}

In economics, the Law of One Price (LOP) states that the price of the same good expressed in the same currency in two different markets should be the same under conditions of competition and without considering transport costs or tariffs (Krugman-Obstfeld 1991). Compliance with the LOP has frequently been studied through analyses comparing price convergence in different countries (Hyvonen 2004, Busetti et al. 2007, Dreger et al. 2007, García-Hiernaux-Guerrero 2015) but to a lesser extent at the intra-national level (Cecchetti et al. 2000; Honohan-Lane 2003, Beck et al. 2009, Gómez Aguirre-Rodriguez Chávez 2014).

Verification of the LOP is more feasible at the intra-national level given the lower transport costs in relation to international trade, the absence of barriers to domestic trade, and the use of the same currency (Dayanandan-Ralhan 2005, Liu et al. 2018). Non-compliance with the LOP at the intra-national level is especially relevant since it implies the presence of regional imbalances, the poor allocation of resources, and differences in the cost of living, which must be taken into account in the system of government transfers (Vashchuk 2003). Further, the persistence of intra-national regional imbalances is of growing interest among researchers (CseteSzabó 2014).

Regional Statistics, Vol. 10. No. 2. 2020: 83-94; DOI: 10.15196/RS100205 
Much research has been conducted to empirically verify the LOP. In this regard, Liu et al. (2018) find evidence of price convergence across Chinese provinces between 2003 and 2015 using a sequential panel selection method. Convergence across cities in Mexico has been reported for the periods 1982-2000 using unit root tests (Sonora 2005) and 1982-2012 through ordinary least squares regression (Gómez Aguirre-Rodriguez-Chávez 2014). Similar results have been found among cities in the United States (Sonora 2008, Huang et al. 2012, Hegwood-Nath 2013). Also in the U.S., empirical evidence has shown the positive effect of e-commerce on regional price convergence (Cavallo 2018).

On the other hand, cointegration techniques have frequently been used to test the validity of the LOP (Goodwin 1992, Jung-Doroodian, 1994, Alavalapati et al. 1997, Kuiper et al. 2002, Silverstovs et al. 2005, Yang et al. 2015, Arruda et al. 2018). Thus, if compliance with this law is accepted, prices in different regions or countries are expected to follow a common long-term trend (that is, they have a similar dynamic) and, therefore, be cointegrated. In this regard, Marcal et al. (2003) found no evidence of cointegration across provinces of Brazil for the 1980-1994 period when using the Johansen cointegration test (1996). Palaia and Holand (2010) extend the analysed period (1980-2006) and admit the possibility of structural breaks following Gregory and Hansen (1996). However, they find no evidence of cointegration.

Lema and Brescia (1998) analyse the cointegration of agricultural prices between Argentina and the United States for 1991-1997 using the test proposed by Engle and Granger (1987) and find results consistent with the idea of cointegration of the series. Also, for Argentina, Daruich and Kozlowski (2019) analyse prices of 22 grocery chains between 2016-2018. Interestingly, a price variance decomposition shows that most of the variance is due to differences across chains and to a lesser extent due to regional differences across stores in the same chain. The above suggests a uniform pricing across regions consistent with the LOP. However, some caveats must be made: these chains have a small number of stores in the poorest areas and they may use subdivisions within the chain to discriminate prices.

Argentina is widely recognized for its territorial disparities; the provinces of northern Argentina have a lower level of development than their central and southern peers. Northern Argentina (Norte Grande Argentino, [NGA]) includes the Noreste ([NEA], Misiones, Corrientes, Chaco, and Formosa) and the Noroeste ([NOA], Salta, Jujuy, Tucumán, Santiago del Estero, Catamarca, and La Rioja). Disparities can be observed in indicators such as infant mortality, life expectancy, gross domestic product (GDP), access to basic services, and poverty (LonghiOsatinsky 2017, González-London 2018, González 2019).

The wide regional disparities have also manifested in price differences within Argentina. In fact, the provinces of the NGA have presented lower prices and costs

Regional Statistics, Vol. 10. No. 2. 2020: 83-94; DOI: 10.15196/RS100205 
of living than the other provinces (INDEC 2002). This translates, for example, into lower monetary poverty lines for the NGA (INDEC 2019a).

After its re-normalization, INDEC published monthly reports in 2016 on the cost of living disaggregated by region. ${ }^{1}$ These monthly reports confirmed that the provinces of the NGA have the lowest price levels, while the provinces of Patagonia have the highest levels. Previously, it was only possible to approximate regional price differences based on household expenditure surveys carried out at irregular intervals of 5-8 years such as the National Household Expenditure Survey (ENGHo in Spanish) conducted in the years 1996/97, 2004/05, 2012/13, and $2017 / 18$

In this context, the present work seeks to analyse compliance with the LOP across regions of Argentina considering the 2016-2019 period. For this, regression techniques are used to test convergence in the cost of living as reported by INDEC. In addition, a cointegration analysis of the series is considered. Hereinafter, section 2 presents the methodology and sources of information. Section 3 describes the results, and section 4 discusses the main conclusions.

\section{Methodology and sources of information}

Considering the objective of this work, ordinary least squares regression analysis is used to test the existence of convergence. This estimation strategy has the advantage of generating more reliable results in small samples than other strategies such as the Generalized Method of Moments (Bao-Dhongde 2009). In particular, the following equation is estimated (Vashchuk 2003, Gómez Aguirre-Rodríguez-Chávez 2014):

$$
\ln \left(\frac{P_{i t}}{P_{i, t-1}}\right)=\alpha+\beta \ln \left(P_{i, t-1}\right)+\rho_{i}+\sigma_{t}+\varepsilon_{i t}
$$

where $\ln \left(P_{i t}\right)$ is the natural logarithm of the chosen price variable $(\mathrm{P})$ in region $i$ in month $t ; \rho_{i}$ are region fixed effects; $\sigma_{t}$ are time fixed effects; and $\varepsilon_{i t}$ is the error term of the model. If there is price convergence, a negative $\beta$ coefficient is expected. In turn, the speed of convergence can be estimated as (Egri-Tánczos 2018, HalkaLeszczynka-Paczesna 2019):

$$
\lambda=-\ln (1+\beta)
$$

A related measure is the balf-life indicator that reflects the number of periods months, in this case - after which $50 \%$ of the price shock is eliminated:

$$
o=\ln (2) / \lambda
$$

While price indices are often used to test convergence, Vashchuk (2003) states that they should be used with caution. In particular, assuming that the price level of all observational units (cities, regions, countries, etc.) being the same in the base

1 INDEC's reports between 2007 and 2015 should be considered with reservations, as demonstrated by Miranda-Zanetti et al. (2019) and González (2020).

Regional Statistics, Vol. 10. No. 2. 2020: 83-94; DOI: 10.15196/RS100205 
period may not be realistic. The foregoing may introduce bias in the choice of the base period and is a reason to prefer the use of nominal prices instead of indices. The following section describes the price variable (total basic basket) used in the regressions.

\section{Sources of information and regionalization}

In the Argentine case, INDEC publishes monthly reports that attempt to approximate the cost of living (in local currency) through the use of a total basic basket per equivalent adult, which includes food and non-food expenses, for regions of Argentina. The considered regions are: the NEA, NOA, Cuyo (Mendoza, San Juan, and San Luis), Centro (Córdoba, Entre Ríos, Santa Fe, La Pampa, and Province of Buenos Aires), Gran Buenos Aires - also known as region Metropolitana - ([GBA], the City of Buenos Aires, and its suburbs), and Patagonia (Rio Negro, Chubut, Neuquén, Santa Cruz, and Tierra del Fuego). The value of the total basic basket is used as input for the construction of a price panel by region. The period under study covers April 2016 to June 2019. Therefore, the panel has 228 observations (region-month combinations).

Simultaneously, since December 2016, a consumer price index has also been made available for regions of Argentina published by INDEC (INDEC 2019b). The CPI quantifies monthly variations of the price level. Unlike the TBB, which is a weighted average of prices, the CPI is an index and therefore has no unit of measure. In addition, the CPI attempts to capture changes in the prices of all goods and services in the economy and therefore has greater breadth than the TBB.

As presented in Figure 1, the Argentine regions cover 24 provinces, including the City of Buenos Aires. The Centro region has the largest proportion of GDP and population, with $66 \%$ and $75 \%$, respectively (INDEC 2004, 2010). On the other hand, the NOA and NEA regions have a lower participation in the GDP than their population contribution, with $4 \%$ and $6 \%$ of GDP and $9 \%$ and $12 \%$ of population respectively. This accounts for the existence of deep regional disparities in Argentina. 


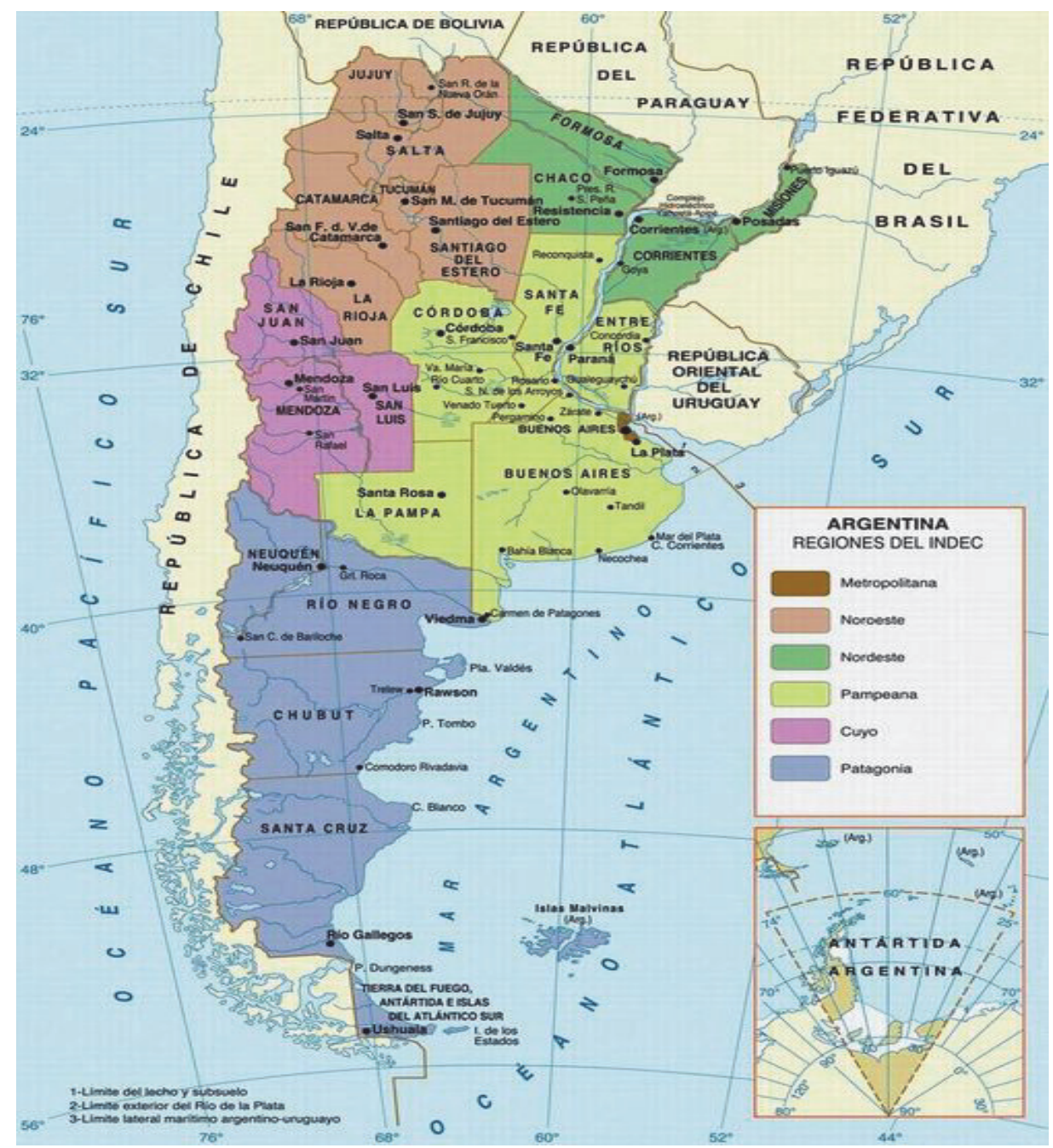

Source: National Institute of Statistics and Census.

\section{Results}

First, the results that arise from estimating equation 1 for regions in Argentina are presented in column 1 of Table 1. Column 2 presents alternative estimates for absolute $\beta$-convergence (without regional fixed effects): 
Convergence in prices across regions of Argentina (2016-2019)

\begin{tabular}{l|c|c}
\hline & $\begin{array}{c}(1) \\
\text { Coefficient }\end{array}$ & $\begin{array}{c}(2) \\
\text { Coefficient }\end{array}$ \\
\hline \multirow{2}{*}{ Estimated $\beta$} & $-0.0384^{* * *}$ & $-0.0003^{* *}$ \\
Regional fixed effects & $(0.00599)$ & $(0.00013)$ \\
Time fixed effects & Yes & No \\
$\mathrm{N}$ & Yes & Yes \\
$\mathrm{R}^{2}$ overall & 228 & 228 \\
& 0.14 & 0.98
\end{tabular}

Note: $*$ significant at $10 \%$, ** significant at $5 \%$, *** significant at $1 \%$.

Source: Author's elaboration based on INDEC.

A negative and significant estimated coefficient is observed in both cases, which is consistent with the idea of price convergence across Argentine regions. When considering an absolute $\beta$-convergence specification (column 2), the estimated coefficient is considerably closer to zero compared to the conditional specification with regional fixed effects, which denotes a lower convergence rate. The estimated coefficients of regional fixed effects of equation 1 (Table 5 of the Annex) confirm that Patagonia has the highest prices and the NEA and NOA regions have the lowest ones, on average. Also, the results are robust when considering alternative periodisations (Table 6 of Annex).

Using the previous results to estimate equations 2 and 3 , the following is obtained: the average convergence rate is $3.9 \%$ monthly, that is, $3.9 \%$ of the deviations from the average are eliminated each month. In turn, the half-life indicator suggests that after 17.7 months, $50 \%$ of the distortions are eliminated.

Second, and as a robustness exercise, equation 1 is re-estimated using the consumer price index published by INDEC as the dependent variable. As mentioned above, the choice of the base period may bias the estimates and, therefore, should be considered with reservations.

Convergence in prices considering the CPI for regions of Argentina (2016-2019)

\begin{tabular}{c|c}
\cline { 2 - 2 } & \multicolumn{1}{c|}{ Coefficient } \\
\cline { 2 - 2 } Estimated $\beta$ & $-0.0347 * * *$ \\
Regional fixed effects & $(0.00900)$ \\
Time fixed effects & Yes \\
$\mathrm{N}$ & Yes \\
$\mathrm{R}^{2}$ overall & 204 \\
Note: $*$ significant at $10 \%, * *$ significant at $5 \%, * * *$ significant at $1 \%$. & 0.93 \\
Source: Author's elaboration based on INDEC.
\end{tabular}

Note: $*$ significant at $10 \%$, ** significant at $5 \%$, *** significant at $1 \%$.

Source: Author's elaboration based on INDEC.

Regional Statistics, Vol. 10. No. 2. 2020: 83-94; DOI: 10.15196/RS100205 
When using the CPI as the dependent variable in the regression, the result of convergence across the regions of Argentina is repeated. Interestingly, the estimated coefficient is similar to that presented in Table 1. The goodness-of-fit of the model improves significantly compared to the previous case. When estimating equations 2 and 3, a slightly lower convergence rate is observed: $3.5 \%$ of the deviations from the mean are eliminated every month and the average life indicator is 19.6 months. This shows that the pace of convergence is higher among goods with greater weight in household spending, such as food and beverages, and included in the TBB than among the overall set of prices in the economy.

A complementary cointegration analysis of the TBB regional series was then conducted. First, the order of integration of the series is analysed and it is observed that all are integrated in order 1; that is, they are not stationary in levels but in first differences. Table 3 presents the results of the Dickey-Fuller test ([ADF], (DickeyFuller, 1979) considering a trend component. Alternatively, other specifications were considered obtaining similar results.

Table 3

\section{P-values for price stationarity analysis by region with ADF test}

\begin{tabular}{l|c}
\hline \multicolumn{1}{c|}{ Region } & First difference \\
\hline GBA & 0.0177 \\
NEA & 0.0073 \\
NOA & 0.0053 \\
Cuyo & 0.0097 \\
Centro & 0.0142 \\
Patagonia & 0.0076
\end{tabular}

Note: the null hypothesis of the ADF test is that the series have a unit root and therefore are non-stationary. Source: Author's elaboration based on INDEC.

It is observed that all series are stationary in first differences at $5 \%$. Thus, given the evidence that the series have the same order of integration, we proceed with the formal analysis of cointegration following the proposal of Engle and Granger (1987):

Table 4

Cointegration of regional price series in Argentina (2016-2019)

\begin{tabular}{l|l|l|l|l|l|l}
\hline \multicolumn{1}{c|}{ Region } & GBA & NEA & NOA & Cuyo & \multicolumn{1}{c|}{ Centro } & Patagonia \\
\hline GBA & -- & $-3.656^{* *}$ & $-3.297^{*}$ & $-3.686^{* *}$ & -3.148 & $-3.800^{* *}$ \\
NEA & & -- & $-3.756^{* *}$ & $-3.527^{* *}$ & $-3.367^{*}$ & -2.892 \\
NOA & & & -- & $-3.785^{* *}$ & $-3.172^{*}$ & -2.967 \\
Cuyo & & & & - & $-3.318^{*}$ & $-3.275^{*}$ \\
Centro & & & & & -- & $-3.904^{* *}$ \\
Patagonia & & & & & & --
\end{tabular}

Note: the null hypothesis of the cointegration test is that the series are not cointegrated. The critical values of the test are: -4.2 (at 1\%), -3.5 (at 5\%), and -3.158 (at 10\%). Since the matrix is symmetric, the complete matrix is not presented to avoid duplication.

Source: Author's elaboration based on INDEC.

Regional Statistics, Vol. 10. No. 2. 2020: 83-94; DOI: 10.15196/RS100205 
The cointegration hypothesis is maintained for regions of Argentina at 10\%. The exceptions are the cases of Greater Buenos Aires-Centro (although with a statistic value very close to the critical value) and Patagonia-NEA/NOA. This is expected considering that Patagonia has the highest price levels, while the provinces of northern Argentina (NEA and NOA) have the lowest prices.

\section{Conclusions}

This work has analysed Argentine regional price dynamics between 2016-2019. It was observed that Argentina has wide territorial disparities, which translates into worse living conditions, income, and education, among others in the northern provinces of the country (Noreste and Noroeste regions).

Since 2016, the national institute of statistics (INDEC in Spanish) has published monthly reports on the cost of living in Argentina by region. At the same time, INDEC began to elaborate price indices by regions (previously only a representative index of the Gran Buenos Aires region was calculated). These data allowed compliance with the Law of One Price across Argentine regions to be empirically tested.

First, a formal convergence analysis was carried out considering the cost of living in Argentine regions. The results showed evidence of conditional and absolute $\beta$ convergence for the analysed period. The convergence rate was estimated at $3.9 \%$ monthly, equivalent to a half-life of the discrepancies of 17.7 months. As a robustness exercise, the previous estimate was reiterated considering the consumer price index (CPI) for Argentine regions. The results were consistent in sustaining the convergence hypothesis, although at a slower rate (estimated speed of 3.5\% per month). All of the above suggests compliance with the Law of One Price in Argentina.

Second, the existence of a stable long-term relationship in regional price dynamics was verified. By using the test proposed by Engle and Granger (1987), which allows comparisons to be made between pairs of regions, evidence consistent with the idea of cointegration of the series was obtained. The exception was given by the Patagonia-NEA and Patagonia-NOA pairs, which is expected, given that northern Argentina has the lowest price levels and Patagonia the highest.

In the future, the implications of this price convergence should be analysed in terms of regional poverty disparities. Indeed, in addition to income differences across regions, if prices in the poorest regions increase more rapidly, this implies that poverty disparities are increasing. In the case of Argentina, it was verified that prices are, on average, lower in the poorest regions (the NEA and NOA) and that these tend to converge at some common level with the prices of other regions. On the other hand, and in order to strengthen the results, it is appropriate to extend the period under analysis and, eventually, disaggregate the findings from the subperiods.

Regional Statistics, Vol. 10. No. 2. 2020: 83-94; DOI: 10.15196/RS100205 


\section{Annex}

\section{Regional fixed effects from equation 1}

Table 5

\begin{tabular}{l|c}
\hline Region & Coefficient \\
\hline NEA & $-0.0069^{* * *}$ \\
& $(0.00108)$ \\
\hline NOA & $-0.0082^{* * *}$ \\
& $(0.00129)$ \\
\hline Pampeana & $-0.0003^{* * *}$ \\
& $(0.00007)$ \\
\hline Patagonia & $0.0059^{* * *}$ \\
& $(0.00094)$ \\
\hline Cuyo & $-0.0019^{* * *}$ \\
& $(0.00030)$
\end{tabular}

Note: * significant at 10\%, ** significant at 5\%,*** significant at 1\%. The Gran Buenos Aires region is the base category.

Source: Author's elaboration based on INDEC.

Table 6

Convergence in prices across regions of Argentina (2016-2019) with quarterly data

\begin{tabular}{l|c}
\hline & Coefficient \\
\hline Estimated $\beta$ & $-0.0258^{* *}$ \\
& $(0.01047)$ \\
Regional fixed effects & Yes \\
Time fixed effects & Yes \\
$\mathrm{N}$ & 13 \\
$\mathrm{R}^{2}$ overall & 0.18
\end{tabular}

Note: $*$ significant at $10 \%$, ** significant at $5 \%$, *** significant at $1 \%$. The values of the total basic basket per equivalent adult were averaged per quarter.

Source: Author's elaboration based on INDEC.

Regional Statistics, Vol. 10. No. 2. 2020: 83-94; DOI: 10.15196/RS100205 


\section{REFERENCES}

Alavalapati, J.-ADAMOWICZ, W.-LUCKERT, M. (1997): A cointegration analysis of Canadian Wood pulp prices American Journal of Agricultural Economics 79 (3): 975-986. https://doi.org/10.2307/1244437

Arruda, E.-CASTElar, I.-Guimaraes, D.-BArbosa, R. (2018): Price convergence, reversal speed and purchasing power parity: stylized facts for Brazilian cities EconomiA 19 (2): 219-235. https://doi.org/10.1016/j.econ.2018.01.001

BAO, Y.-Dhongde, S. (2009): Testing Convergence in Income Distribution Oxford Bulletin of Economics and Statistics 71 (2): 295-302. https://doi.org/10.1111/j.1468-0084.2008.00514.x

Beck, G.-Hubrich, K.-MARCEllino, M. (2009): Regional Inflation dynamics within and across euro area countries and a comparison with the United States Economic Policy 24 (1): 141-184. https://doi.org/10.1111/j.1468-0327.2009.00214.x

BusetTi, F.-Forni, L.-Harvey, A.-VenditTi, F. (2007): Inflation Convergence and Divergence within the European Monetary Union International Journal of Central Banking 3 (2): 95-121.

Cavallo, A. (2018): More Amazon effects: online competition and pricing behaviors NBER Working paper No. 25138. https://doi.org/10.3386/w25138

CeCChetTI, S.-MARK, N.-SONORA, R. (2000): Price level convergence among United States cities: lessons for the European central bank NBER Working paper No. 7681. https://doi.org/10.3386/w7681

CSETE, M.-SZABÓ, M. (2014): How the spatial distribution of the Hungarian TOP 500 companies affects regional development: an examination of income generation at subnational scale Regional Statistics 4 (1): 40-60. http://dx.doi.org/10.15196/RS04104

DARUiCH, D-KOZlOwSKI, J. (2019): Macroeconomic implications of uniform pricing Working paper 2019-024 A Federal Reserve Bank of St. Louis, St. Louis.

Dayanandan, A.-RAlHan, M. (2005): Price index convergence among provinces and cities across Canada: 1978-2001 Working paper EWP0504 University of Victoria, Victoria.

DiCKEY, D.-FulLER, W. (1979): Distribution of the Estimators for Autoregressive Time Series with a Unit Root Journal of the American Statistical Association 74 (366): 427-431. https://doi.org/10.1080/01621459.1979.10482531

Dreger, C.-Kholodilin, K.-Lommatzsch, K.-SlacaleK, J.-WoZniak, P. (2007): Price convergence in the enlarged internal market Working paper No. 292, European Commission, Brussels.

ENGLE, R.-GRANGER, C. (1987): Co-integration and error correction: representation, estimation and testing Econometrica 55 (2): 251-276. https://doi.org/10.2307/1913236

EGRI, Z.-TÁNCZOS, T. (2018): The spatial peculiarities of economic and social convergence in Central and Eastern Europe Regional Statistics 8 (1): 49-77. https://doi.org/10.15196/RS080108

García-Hiernaux, A.-Guerrero, D. (2015): Price-level convergence in the Eurozone. Working paper No. 1505. Instituto Complutense de Análisis Económico, Madrid.

Regional Statistics, Vol. 10. No. 2. 2020: 83-94; DOI: 10.15196/RS100205 
Gómez Aguirre, M.-RodrigueZ-CháveZ, J. (2014): Convergencia de precios en México Revista CIMEXUS 8 (2): 95-105.

GONZÁLEZ, F. (2019): Access to an improved water source and its measurement: the case of Misiones (Argentina) Orbis Latina 9 (2): 53-65.

GONZÁLEZ F. (2020): Self-reported income data: are people telling the truth? Journal of Financial Crime 27 (2), in press. https://doi.org/10.1108/JFC-08-2019-0113

GONZÁLEZ, F.-LONDON, S. (2018): Aportes a la identificación y cuantificación de las externalidades de la foresto-industria: el caso de Puerto Piray (Misiones, Argentina) SaberEs 10 (2): 129-151.

GoODwIN, B. (1992): Multivariate cointegration tests and the law of one price in international wheat markets Applied Economic Perspectives and Policy 14 (1): 117-124. https://doi.org/10.2307/1349612

GREgORY, A.-HANSEN, B. (1996): Residual-based tests for cointegration in models with regime shifts Journal of Econometrics 70 (1): 99-126. https://doi.org/10.1016/0304-4076(69)41685-7

HALKA, A.-LeSZCZYNKA-PACZESNA, A. (2019): Price convergence in the European Union: what has changed? Economic Modelling 79: 226-241. https://doi.org/10.1016/j.econmod.2018.11.002

HeGwood, N.-NATH, H. (2013): Structural breaks and relative price convergence among US cities Journal of Macroeconomics 36 (6): 150-160. https://doi.org/10.1016/j.jmacro.2012.12.006

Honohan, P.-LAne, P. (2003): Divergent Inflation Rates in EMU Economic Policy 18 (37): 357-394.

HUANG, H.-LIU, W.-YEH, C. (2012): Convergence in price levels across US cities Economics Letters 114 (3): 245-248. https://doi.org/10.1016/j.econlet.2011.09.039

HYvONEN, M. (2004): Inflation convergence across countries Working paper rdp2004-04 Reserve Bank of Australia, Sydney.

JOHANSEN, S. (1996): Likelihood-based inference in cointegrated vector autoregressive models Oxford University Press, London.

Jung, C.-Doroodian, K. (1994): The law of one price for U.S. softwood lumber: a multivariate cointegration test Forest Science 40 (4): 595-600.

Krugman, P.-Obstfeld, M. (1991): Economía Internacional. Teoría y política McGraw-Hill, New York.

Kuiper, W.-Lutz, C.-Tilburg, A. (2002): Testing for the law of one Price and identifying price-leading markets: an application to corn markets in Benin Journal of Regional Science 39 (4): 713-738. https://doi.org/10.1111/0022-4146.00157

LEMA, D.-BresciA, V. (1998): La convergencia de los precios agrícolas de la Argentina y EE.UU.: "La Ley de un solo precio" para los commodities pampeanos Working paper No. 2, INTA.

LiU, T.-SU, S.-CHANG, H.-CHU, C. (2018): Convergence of regional housing prices in China Journal of Urban Planning and Development 144 (2) https://doi.org/10.1061/(ASCE)UP.1943-5444.0000451

LONGHI, F.-OSATINSKY, A. (2017): Estructura productiva, pobreza y problemas de empleo en las provincias pampeanas y norteñas de Argentina en los primeros años del siglo XXI. Cuadernos de Geografía 26 (1): 77-99.

https://doi.org/10.15446/rcdg.v26n1.51011

Regional Statistics, Vol. 10. No. 2. 2020: 83-94; DOI: 10.15196/RS100205 
Marcal, E.-Pereira, P.-Santos Filho, O. (2003): Paridade do poder de compra: testando dados brasileiros Revista Brasileira de Economia 57 (1): 159-190. https://doi.org/10.1590/S0034-71402003000100006

Miranda-ZanetTi, M.-Delbianco, F.-TohmÉ, F. (2019): Tampering with inflation data: a Benford law-based analysis of national statistics in Argentina Physica $A$ 525: 761-770. https://doi.org/10.1016/j.physa.2019.04.042

Palaia, D.-Holand, M. (2010): Taxa de Câmbio e Paridade de Poder de Compra no Brasil: Análise Econométrica com Quebra Estrutural Economia Aplicada 14 (1): 5-24. https://doi.org/10.1590/S1413-80502010000100001

Silverstovs, B.-L'HÉgAret, G.-VON HirschHAusen, C. (2005): International market integration for natural gas? A cointegration analysis of prices in Europe, North America and Japan Energy Economics 27 (4): 603-615. https://doi.org/10.1016/j.eneco.2005.03.002

SONORA, R. (2005): City CPI convergence in Mexico Review of Development Economics 9 (3): 359-367. https://doi.org/10.1111/j.1467-9361.2005.00281.x

SONORA, R. (2008): Bivariate relative city price convergence in the United States: 1918-1997 Review of Financial Economics 17 (2): 92-111. https://doi.org/10.1016/j.rfe.2007.02.010

YANG, J.-Bessler, D.-Leatham, L. (2000): The law of one price: developed and developing country market integration Journal of Agricultural and Applied Economics 32 (3): 429-440. https://doi.org/10.1017/S107407080002054X

\section{INTERNET REFERENCES}

INDEC (2002): Paridades de poder de compra del consumidor Dirección de Índices de precio de consumo https://www.indec.gov.ar/nuevaweb/cuadros/10/PPCC-Metodologia.pdf (downloaded: 10 December 2019)

INDEC (2004): Producto Bruto Interno por Provincia. Año 2004 https://sitioanterior.indec.gob.ar/nivel4_default.asp?id_tema_1=3\&id_tema_2= 9\&id_tema_3=138 (downloaded: 10 December 2019)

INDEC (2010): Resultados del Censo Nacional de Población, Hogares y Viviendas 2010 https://sitioanterior.indec.gob.ar/nivel4_default.asp?id_tema_1=3\&id_tema_2= 9\&id_tema_3=138 (downloaded 10 December 2019)

INDEC (2019a): Serie Informes Técnicos de Condiciones de Vida: incidencia de la pobreza y la indigencia en 31 aglomerados urbanos https://www.indec.gob.ar/indec/web/Nivel4-Tema-446-152 (downloaded: 10 December 2019)

INDEC (2019b): Serie Informes Técnicos Índice de Precios al Consumidor https://www.indec.gob.ar/indec/web/Nivel4-Tema-3-5-31 (downloaded: 10 December 2019)

VAshCHUK, O. (2003): The law of one Price and regional price convergence in Ukraine. Tesis de Maestría en Economía de la Universidad Nacional de Kyiv-Mohyla Academy, Kiev.

http://www.kse.org.ua/uploads/file/library/2003/Vashchuk.pdf (downloaded: 10 December 2019)

Regional Statistics, Vol. 10. No. 2. 2020: 83-94; DOI: 10.15196/RS100205 